\title{
O ART. 14 DA LEI ANTICORRUPÇÃO SOB O CRIVO DA JURISDIÇÃO CONSTITUCIONAL: INCONSTITUCIONALIDADE NO MODO DE DESCONSIDERAÇÃO DA PERSONALIDADE JURÍDICA
}

\author{
THE ARTICLE 14 ANTI-CORRUPTION LAW UNDER THE CRITERIA OF CONSTITUTIONAL \\ JURISDICTION: UNCONSTITUTIONALITY IN THE MODE OF DECIDERATION OF LEGAL \\ PERSONALITY
}

\begin{abstract}
Jussara Suzi Assis Borges Nasser Ferreira
Doutora em Direito das Relações Sociais pela Pontifícia Universidade Católica de São Paulo - PUC. Professora Permanente do Programa de Doutorado e Mestrado em Direito da Universidade de Marília - UNIMAR e do Programa de Mestrado em Direito e Cidadania da Universidade Paranaense - UNIPAR. Advogada. E-mail: jussara@bflaw.adv.br

\section{André Francisco Cantanhede Menezes}

Doutorando em Direito pela Universidade de Marília. Mestre em Gestão e Desenvolvimento Regional pela Universidade de Taubaté. Professor universitário na Universidade Federal do Maranhão. Advogado.

E-mail: andrefcmenezes@gmail.com
\end{abstract}

Recebido em: 21/08/2019

Aprovado em: 15/04/2020

RESUMO: Ante o avanço de práticas corruptivas, a comunidade internacional se movimentou e, por meio de tratados internacionais, ratificou a responsabilidade dos Estados na prevenção e repressão da corrupção. O Brasil, como signatário de algumas dessas convenções e a fim de darlhes cumprimento, dentre outras posturas, editou a Lei $n^{\circ} 12.846 / 2013$, que prevê a possibilidade da desconsideração da personalidade jurídica por via de processo administrativo de responsabilização. Considerada a redação do art. 14, daquela Lei, afigura-se legal e constitucional se desconsiderar a personalidade jurídica de um sujeito empresário por via de processo administrativo, sem intervenção da Jurisdição? Objetiva-se, dada a conformação substancial do instituto da desconsideração da personalidade jurídica, notadamente, após as modificações inseridas pela Lei da Liberdade Econômica, analisar os aspectos procedimentais trazidos pela Lei Anticorrupção, sobretudo, frente à nova dogmática inaugurada pelo CPC de 2015 e, mais ainda, considerados os princípios e preceitos constitucionais aplicáveis à matéria. Trata-se de pesquisa exploratória, com abordagem qualitativa e com delineamento a partir da revisão de literatura. Vislumbra-se que o devido processo legal que se espera, neste caso, é o que se origina, desenrola e conclui sob a batuta da Jurisdição, única função estatal apta a atuar no deslinde da questão. Conclui-se que, sobre o crivo da jurisdição constitucional, o conteúdo normativo do art. 14, da Lei $\mathrm{n}^{\mathrm{o}} 12.846 / 2013$, revela-se inconstitucional.

Palavras-chave: Corrupção; Desconsideração; Personalidade Jurídica; Jurisdição constitucional; Processo administrativo. 
ABSTRACT: Faced with the advance of corrupt practices, the international community moved and, through international treaties, ratified the responsibility of states to prevent and repress corruption. Brazil, as a signatory to some of these conventions and in order to comply with them, among other attitudes, issued Law $\mathrm{n}^{\mathrm{o}}$ 12.846/2013, which provides for the possibility of disregarding legal personality through an administrative process of accountability. Considering the wording of art. 14, of Law $\mathrm{n}^{\mathrm{o}} 12.846 / 2013$, does it seem legal and constitutional if it disregards the legal personality of an entrepreneur subject through administrative process, without intervention of the Jurisdiction? The objective is, given the substantial conformation of the institute of disregarding the legal personality, notably, after the modifications inserted by the Law of Economic Freedom, to analyze the procedural aspects brought by the Anticorruption Law, above all, in face of the new dogmatic inaugurated by the CPC of 2015 and, moreover, considering the constitutional principles and precepts applicable to the matter. This is an exploratory research with a qualitative approach and outlined from the literature review. It is clear that the due legal process that is expected, in this case, is the one that originates, unfolds and concludes under the baton of Jurisdiction, the only state function able to act on the issue. Thus, regarding the sieve of constitutional jurisdiction, the normative content of art. 14, of Law $\mathrm{n}^{\mathbf{0}}$ 12.846/2013, is unconstitutional.

Keywords: Corruption; Disregard; Legal personality; Constitutional jurisdiction; Administrative process.

SUMÁRIO: Introdução. 1 A lei anticorrupção e o ponto de interesse. 2 A personalidade jurídica de um sujeito empresário. 3 A desconsideração da personalidade jurídica. $4 \mathrm{O}$ artigo 14 da Lei $\mathrm{N}^{\circ}$ 12.846/2013 e sua debilidade. 4.1 Conflito de normas. $4.2 \mathrm{O}$ ainda incipiente entendimento do STJ. 4.3 Ilegalidade e lesão a preceitos constitucionais. Conclusão. Referências.

\section{INTRODUÇÃO}

No contexto de condutas eivadas de desvios morais e éticos praticadas por agentes no exercício direto ou indireto da função pública, a corrupção se destaca como elemento maculador de certas atividades privadas e da própria Administração Pública com consequências danosas à conformação social hígida e ao desenvolvimento socioeconômico local.

Com escopo de suprir a lacuna existente no ordenamento jurídico brasileiro quanto à específica responsabilização de pessoas jurídicas pela prática de atos ilícitos em face da Administração, bem como atender aos compromissos internacionais assumidos pelo Brasil no combate à corrupção, editou-se a Lei no 12.846/2013, intitulada Lei Anticorrupção.

Tem-se, conforme o parágrafo único, do art. $1^{\circ}$ desta Lei, que suas disposições são aplicáveis às sociedades empresárias e às simples, personificadas ou não, independentemente da forma de organização ou modelo societário adotado, bem como a quaisquer fundações, associações de entidades, pessoas ou sociedades estrangeiras, que tenham sede, filial ou representação no território brasileiro, constituídas de fato ou de direito, ainda que temporariamente.

Entretanto, dá-se, neste estudo, ênfase aos efeitos dessa lei somente perante sujeitos empresários que podem adquirir personalidade jurídica. Em outras palavras, levando-se em conta o rol do art. 44, do Código Civil, considera-se apenas a empresa individual de responsabilidade limitada, conhecida como EIRELI (art. 980-A, do CC) e a sociedade empresária (art. 981 e seguintes, do CC).

A título de problema desta pesquisa, conforme art. 14, da Lei ${ }^{\circ}$ 12.846/2013, afigura-se legal e constitucional se desconsiderar a personalidade jurídica de um sujeito empresário no bojo de um processo administrativo, ou seja, sem intervenção da Jurisdição? 
Dada a conformação substancial do instituto da desconsideração da personalidade jurídica, notadamente, após a atualização trazida pela Lei $n^{\circ} 13.874 / 2019$, chamada Lei da Liberdade Econômica - que, ao estabelecer normas de proteção à livre iniciativa e ao livre exercício de atividade econômica, modificou, dentre outros, o Código Civil, a se ver de seus artigos 49-A e 50 -, objetiva-se analisar, segundo as balizas da jurisdição constitucional, os aspectos procedimentais trazidos por aquele dispositivo específico previsto na Lei Anticorrupção, sobretudo frente à nova dogmática adjetiva inaugurada pelo Código de Processo Civil-CPC de 2015 e, mais ainda, considerados os princípios e preceitos constitucionais aplicáveis à matéria.

Impende destacar que, neste trabalho, não se está a discutir temas inerentes à corrupção e respectivas práticas anticorrupção propriamente ditas, mas o instituto da desconsideração da personalidade jurídica de sujeitos empresários segundo a forma procedimental estabelecida no Capítulo IV da Lei n ${ }^{\circ}$ 12.846/2013, especialmente, considerado seu art. 14.

Justifica-se o estudo deste assunto, pois, a uma, há de se extirpar o conflito de normas instrumentais no tempo entre o art. 14, da Lei n $^{\circ} 12.846 / 2013$ e o art. 133 e seguintes do novo CPC. A duas, sendo cediço que se deve manter incólume a supremacia constitucional, sobretudo, quanto ao comando de se observar a reserva de jurisdição (esta, enquanto função estatal), para consecução desse fim, considerado o caso posto, o conteúdo normativo daquele dispositivo da Lei Anticorrupção há de ser submetido à interpretação e aplicação da Constituição por órgãos judiciais investidos no exercício da jurisdição constitucional.

Trata-se de pesquisa exploratória, com abordagem qualitativa e com delineamento a partir da revisão de literatura. No desenvolvimento discorrer-se-á, em especial, sobre a Lei Anticorrupção, personalidade jurídica e sua desconsideração e (im)possibilidade de se realizar este procedimento estritamente na essência do processo administrativo, como prevê a Lei $n^{\circ} 12.846 / 2013$.

Conclui-se que, posto o art. 14, da Lei $n^{\circ} 12.846 / 2013$ sob o crivo da jurisdição constitucional, este há de ser declarado inválido, pois inconstitucional. Em outras palavras, apesar de ser louvável toda e qualquer intenção de se extirpar a corrupção, o legislador ordinário não pode se desgarrar do dever de observar os princípios constitucionais da separação dos poderes, reserva de jurisdição, do devido processo legal e do juiz natural, por exemplo.

\section{A LEI ANTICORRUPÇÃO E O PONTO DE INTERESSE}

Em um Estado Democrático e de Direito interessa saber como ocorre a relação entre o setor privado e o público, principalmente, no que diz respeito à alocação e aplicação de recursos. "Fato é que o aparato estatal contém espaços atrativos à ação da corrupção, notadamente a prestação e a contratação de serviços públicos, a concessão de empréstimos públicos, a concessão de benefícios e incentivos fiscais e a conquista de postos políticos" (ZANETTI, 2016, p. 39).

Em que pese seus múltiplos aspectos e definições, Rosa (2004, p. 18) aduz que:

Na perspectiva do Direito, a corrupção é ilícito retratador de conduta humana que desafia valores éticos os quais devem presidir o manejo da coisa pública. É ilícito pluriobjetivo, que permite a reprovação sob a ótica do Direito Penal (porque constitui crime), sob a ótica civil (porque obriga a reparação do dano ou prejuízo), sob o enfoque exclusivamente funcional (porque constitui antes falta funcional), além de admitir sanção de natureza outra, comportando a reprovação política (por violação de decoro e infidelidade do político).

Desse modo, não obstante existirem leis que definem crimes, atos de improbidade e infrações administrativas praticados em face da Administração Pública, sinalizando a intenção de efetivamente coibir essas práticas, o legislador ordinário se ocupou em legiferar especificamente 
acerca dos ilícitos praticados por pessoas jurídicas contra a Administração Pública, nacional ou estrangeira. Emerge, pois, a Lei no 12.846/2013, também conhecida como Lei Anticorrupção.

Para fins dessa lei, constituem atos lesivos à administração pública, nacional ou estrangeira, todos aqueles praticados pelas pessoas jurídicas mencionadas no parágrafo único de seu art. $1^{\circ}$, que atentem contra o patrimônio público nacional ou estrangeiro, contra princípios da administração pública ou contra os compromissos internacionais assumidos pelo Brasil (art. $5^{\circ}$ ). Consta ali que a responsabilização da pessoa jurídica não exclui a responsabilidade individual de seus dirigentes ou administradores ou de qualquer pessoa natural, autora, coautora ou partícipe do ato ilícito $\left(\operatorname{art} .3^{\circ}\right)$.

No seu escopo de atuação:

Além de atender a compromissos internacionais assumidos pelo Brasil, a lei fecha uma lacuna no ordenamento jurídico do país ao tratar diretamente da conduta dos corruptores. A Lei Anticorrupção prevê punições como multa administrativa - de até $20 \%$ do faturamento bruto da empresa - e o instrumento do acordo de leniência, que permite o ressarcimento de danos de forma mais célere, além da alavancagem investigativa.

O Ministério da Transparência e Controladoria-Geral da União (CGU) é responsável grande parte dos procedimentos como instauração e julgamento dos processos administrativos de responsabilização e celebração dos acordos de leniência no âmbito do Poder Executivo Federal (CGU, 2018, p. 1).

Sob esta perspectiva, tem-se que, para fins de aplicação das sanções previstas no $\operatorname{art} .6^{\circ}$ da Lei $\mathrm{n}^{\circ}$ 12.846/2013, a autoridade administrativa deverá se valer do nominado Processo Administrativo de Responsabilização (PAR) para apurar as condutas e responsabilidade administrativa de pessoa jurídica.

A instauração e o julgamento de processo administrativo para apuração da responsabilidade de pessoa jurídica cabem à autoridade máxima de cada órgão. Será ele conduzido por comissão designada pela autoridade instauradora e composta por 2 (dois) ou mais servidores estáveis, que deverá concluir o processo no prazo de 180 (cento e oitenta) dias contados da data da publicação do ato que a instituir (podendo ser prorrogado mediante ato fundamentado da autoridade instauradora) e, ao final, apresentar relatórios sobre os fatos apurados e eventual responsabilidade da pessoa jurídica, sugerindo de forma motivada as sanções a serem aplicadas.

Seguindo-se, é concedido à pessoa jurídica prazo de 30 (trinta) dias para defesa e, concluído o processo e não havendo pagamento, o crédito apurado será inscrito em dívida ativa da fazenda pública. Esta sequência de atos vem listada do art. $8^{\circ}$ até o art. 15, daquela lei.

Fixadas essas bases, mas volvendo-se ao cerne deste trabalho, reitera-se que não se cuida de analisar a corrupção e respectivas práticas anticorrupção. O enfoque é outro, notadamente, no que concerne a se esmiuçar o tratamento legal dado ao instituto da desconsideração da personalidade jurídica pela Lei no $12.846 / 2013$.

Com efeito, o ponto central da discussão aqui proposta reside, não no conteúdo material do art. 14, da Lei $\mathrm{n}^{\mathrm{o}}$ 12.846/2013 (pois, este, indene de dívidas, se amolda às outras hipóteses de incidência da desconsideração da personalidade jurídica em outros ramos do Direito), mas sim no aspecto procedimental para se proceder à desconsideração ali prevista. Aquele artigo está assim redigido:

Art. 14. A personalidade jurídica poderá ser desconsiderada sempre que utilizada com abuso do direito para facilitar, encobrir ou dissimular a prática dos atos ilícitos previstos nesta Lei ou para provocar confusão patrimonial, sendo estendidos todos os efeitos das sanções aplicadas à pessoa jurídica aos seus 
administradores e sócios com poderes de administração, observados o contraditório e a ampla defesa.

Sua alocação no corpo daquela lei o faz pertencer à disciplina do Processo Administrativo de Responsabilização, porquanto, um dos meios para se obter o objetivo da Lei Anticorrupção. Tem-se, assim o ponto controvertido, pois, segundo a Lei poder-se-ia desconsiderar a personalidade jurídica de um sujeito empresário no âmago de um processo administrativo, sem intervenção da jurisdição. Isso leva a se perquirir sobre a legalidade e constitucionalidade daquele dispositivo legal.

\section{A PERSONALIDADE JURÍDICA DE UM SUJEITO EMPRESÁRIO}

Tomando-se por base a teoria da realidade, segundo a qual o Direito pode criar suas próprias instituições e entes, tem-se que pessoa jurídica, na definição de Diniz (2011, p. 49), é "a unidade de pessoas naturais ou de patrimônios, que visa à consecução de certos fins, reconhecida pela ordem jurídica como sujeito de direitos e obrigações". Disso decorre que "a personalidade jurídica pode ser definida como a aptidão genérica para adquirir direitos e contrair obrigações" (DINIZ, 2011, p. 27; SILVA, 2015, p. 20).

Essa personalidade, atributo da pessoa jurídica, tem natureza jurídica de direito constitucional fundamental, pois, signo identificador e distintivo, tal qual, aponta o inciso XXIX, do art. $5^{\circ}$, da Constituição, gozando, pois, das características dos direitos fundamentais.

Nesse cenário, mais sensível a percepção de aquisição de personalidade jurídica por um empresário, dada a atividade por ele exercida na ordem econômica. E é justamente neste ponto que se tem o recorte espacial deste estudo, no qual não se aborda a personalidade jurídica e seus efeitos em relação aos outros sujeitos descritos no art. 44, do CC, mas tão somente em relação àqueles que podem figurar como empresários.

Nos termos do art. 966, do Código Civil, considera-se empresário o sujeito que, seja pessoa física ou jurídica, exerce profissionalmente atividade econômica organizada para a produção ou a circulação de bens ou de serviços. Desta definição legal se pode extrair o que significa empresa, a saber, nada mais que a atividade econômica organizada exercida profissionalmente pelo empresário. Portanto, empresário e empresa, em que pese serem utilizados pelo senso comum como expressões sinônimas, não o são, pois, caracterizados como termos técnicos, têm significância própria: "aquele se refere a uma pessoa que exerce uma atividade, já a empresa é a própria atividade exercida pelo sujeito" (DINIZ, 2018, p. 388-390).

O sujeito empresário poderá ser uma pessoa física ou jurídica. Se física, exercerá empresa em nome próprio, com unicidade patrimonial e na forma de empresário individual (art. 972, do $\mathrm{CC}$ ). Entretanto, acaso se queira exercer empresa por meio de uma pessoa jurídica este novo sujeito empresário poderá ser constituído ou como empresa individual de responsabilidade limitada, conhecida como EIRELI (art. 980-A, do CC), ou como uma sociedade empresária (art. 981 e seguintes, do CC); e, desde que, em qualquer uma dessas modalidades, proceda-se à inscrição do ato constitutivo no respectivo registro, precedida, quando necessário, de autorização ou aprovação do Poder Executivo (artigos 45, 967, 985 e 1.150, todos do CC).

Isso, pois, cediço que, na forma do art. 45, do Código Civil, começa a existência legal das pessoas jurídicas de direito privado com a inscrição do instrumento de sua criação (ato constitutivo; contrato social), no Registro Público de Empresas Mercantis-REPM. Valendo-se do art. $1^{\circ}$, da Lei $\mathrm{n}^{\text {o }} 8.934 / 1994$, Negrão $(2018$, p. 154) afirma que "o registro, nesse contexto, tem a finalidade de dar garantia, publicidade, autenticidade, segurança e eficácia aos atos jurídicos das empresas mercantis".

Em outras palavras, assentado está que os sujeitos elencados no art. 44 do CC adquirirão personalidade jurídica a partir do momento em que houver o registro de seus atos constitutivos nos 
respectivos órgãos específicos (Registro Civil de Pessoas Jurídicas-RCPJ, Junta Comercial ou órgãos de classe), a depender da atividade que desempenharão, pois nem toda pessoa jurídica será sujeito empresário. Como exemplo disso, indene de dúvidas que uma cooperativa é um tipo de sociedade e pode ser uma pessoa jurídica se houver registro de seu estatuto, mas nunca será sujeito empresário nos termos do parágrafo único do art. 982, do CC e do art. $3^{\circ}$, da Lei n 5.764/1971.

Feitas essas parametrizações terminológicas, retoma-se o objeto, acima de tudo, para se consignar que, de todo modo, o principal efeito da aquisição de personalidade jurídica é a possibilidade de se ter autonomia patrimonial, pois:

Em regra a sociedade responde, para o cumprimento de suas obrigações, com seus bens presentes e futuros. É a chamada responsabilidade primária. Esse conceito também se aplica à empresa individual de responsabilidade limitada. $\mathrm{O}$ patrimônio pessoal dos sócios fica sujeito à execução, secundariamente, nos termos do contrato social, de acordo com o que a lei dispuser para o tipo social escolhido. Nas empresas individuais de responsabilidade limitada e nas sociedades limitada e anônima, espécies mais difundidas no meio empresarial, uma vez integralizado o capital social, não há sequer responsabilidade secundária, respondendo unicamente o patrimônio social. Em ambos os casos atende-se ao princípio da autonomia patrimonial. Cada patrimônio responde pelas obrigações assumidas por seu titular (NEGRÃO, 2018, p. 61).

Veja-se que a partir do momento que um instituidor constitui uma EIRELI ou que sócios constituem uma sociedade, e, em ambos os casos, procede-se à inscrição dos atos constitutivos no órgão de registro competente, nascem novos sujeitos (EIRELI e sociedade), agora com uma personalidade que é jurídica, diversos estes sujeitos, pois, daquelas pessoas que apenas os constituíram.

Com escopo de ratificar isso, o legislador ordinário inseriu no Código Civil, por meio da Lei $\mathrm{n}^{\circ}$ 13.874/2019, diretriz normativa de cunho eminentemente explicativo, a aclarar que "a pessoa jurídica não se confunde com os seus sócios, associados, instituidores ou administradores", conforme o novel art. 49-A, obstando, desta forma, a possível invocação de responsabilidades e obrigações cumulativas.

Anota Vido (2015, p. 167) que "a constituição da personalidade jurídica viabiliza a realização de algumas atividades que seriam inexequíveis sem ela, seja pelo montante investido ou simplesmente pelo risco assumido". Dessa aquisição de personalidade jurídica ressai o princípio da autonomia de patrimônio: a pessoa jurídica tem patrimônio distinto dos sócios ou instituidor que lhe deram azo.

Sendo a pessoa jurídica um sujeito diverso daqueles que lhe deram origem (art. 49-A, do CC), esta se vale de patrimônio próprio e autônomo dos de seus instituidores ou sócios, para cumprir seu mister, pois, é um instrumento lícito de alocação e segregação de riscos, estabelecido pela lei. Neste ponto, a Lei $\mathrm{n}^{\mathrm{o}} 13.874 / 2019$, ao modificar o Código Civil, descortina que a autonomia patrimonial das pessoas jurídicas tem por finalidade estimular empreendimentos para a geração de empregos, tributo, renda e inovação em benefício de todos, conforme parágrafo único, do art. 49-A, do CC (RODRIGUES JÚNIOR, 2019, p. 123-127).

Entretanto, o exercício de atividade empresária sob a forma de empresa individual de responsabilidade limitada ou de sociedade, para alguns instituidores ou sócios acaba por incentivar a prática de condutas escusas em abuso, prestando-se a sociedade ou a EIRELI como ser imaterial servidor de abrigo ao fraudador, haja vista a limitação de alcance do patrimônio. Com efeito, é comum haver situações nas quais os sócios se valem dessa blindagem patrimonial trazida pela aquisição de personalidade jurídica para fraudar a lei.

Nesse sentido, a doutrina e a jurisprudência desenvolveram mecanismos, hodiernamente já fixados em lei, para descortinar a pessoa jurídica, retirando o véu protetor, viabilizando o alcance 
daqueles que se camuflam (sócios ou instituidor, no caso de empresa individual de responsabilidade limitada).

\section{A DESCONSIDERAÇÃO DA PERSONALIDADE JURÍDICA}

Emerge, nesse sentido, a chamada disregard of legal entity, teoria da desconsideração da personalidade jurídica (também conhecida como teoria do superamento da personalidade jurídica ou teoria da penetração). Assim, está autorizada a aplicação da teoria da desconsideração da personalidade jurídica para alcançar o sócio/administrador que cometeu a fraude, buscando-se modificar o centro de imputação de responsabilidade por certas e determinadas obrigações. Dito de outro modo: a obrigação que recairia sobre a sociedade, recairá sobre o sócio.

Estabelecendo a nominada teoria maior da desconsideração, reza o art. 50, do CC (em sua novel redação dada pela Lei $\mathrm{n}^{\circ}$ 13.874/2019) que, em caso de abuso da personalidade jurídica, caracterizado pelo desvio de finalidade ou pela confusão patrimonial, pode o juiz decidir, a requerimento da parte ou do Ministério Público, quando lhe couber intervir no processo, que os efeitos de certas e determinadas relações de obrigações sejam estendidos aos bens particulares dos administradores ou sócios da pessoa jurídica (DINIZ, 2011; NEGRÃO, 2018; VIDO, 2015).

No particular do art. 50, do CC, os dois eixos que estruturam o abuso de personalidade, a saber, o desvio de finalidade e a confusão patrimonial, são agora balizados em suas definições e hipóteses em que hão de incidir no caso concreto. Com efeito, o desvio de finalidade é a utilização da pessoa jurídica com o propósito de lesar credores e para a prática de atos ilícitos de qualquer natureza. Lado outro, entende-se por confusão patrimonial a ausência de separação de fato entre os patrimônios da pessoa jurídica e de seus sócios ou instituidor, caracterizada, por exemplo, pelo cumprimento repetitivo pela sociedade de obrigações do sócio ou do administrador ou vice-versa, ou, transferência de ativos ou de passivos sem efetivas contraprestações, desde que em valores significativos.

Em que pese o regramento delimitativo do artigo sob análise, no parágrafo $2^{\circ}$, inciso III, adotou-se conceito aberto com vistas a contemplar outras possíveis situações, "consoante outros atos de descumprimento da autonomia patrimonial". O parágrafo $3^{\circ}$, contempla a aplicação da desconsideração inversa com acerto, ao estabelecer: "O disposto no caput e nos $\S \S 1^{\circ}$ e $2^{\circ}$ deste artigo também se aplica à extensão das obrigações de sócios ou de administradores à pessoa jurídica", tendo por fim coibir o uso da empresa pelo sócio para blindar o patrimônio, e assim não ser alcançado pelos credores. Por meio da Lei no $13.874 / 2019$, emana do art. 50, $\S 4^{\circ}$ do CC, que a mera existência de grupo econômico sem a presença dos requisitos de que trata o caput deste artigo não autoriza a desconsideração da personalidade da pessoa jurídica. Arrematando, a regra do parágrafo $5^{\circ}$, excepciona para assegurar que "não constitui desvio de finalidade a mera expansão ou a alteração da finalidade original da atividade econômica.

De outro lado, levando-se em conta outro aspecto material de incidência, o juiz poderá desconsiderar a personalidade jurídica quando, em detrimento do consumidor, houver abuso de direito, excesso de poder, infração da lei, fato ou ato ilícito ou violação dos estatutos ou contrato social. A desconsideração também será efetivada quando houver falência, estado de insolvência, encerramento ou inatividade da pessoa jurídica provocados por má administração, bem ainda, sempre que a personalidade jurídica for, de alguma forma, obstáculo ao ressarcimento de prejuízos causados aos consumidores. Esta vertente caracteriza a teoria menor, estampada no art. 28, caput e $\S 5^{\circ}$, do Código de Defesa do Consumidor-CDC (NEGRÃO, 2018).

Há ainda aplicação da disregard of legal entity em outras áreas do Direito: poderá ser desconsiderada a pessoa jurídica sempre que sua personalidade for obstáculo ao ressarcimento de prejuízos causados à qualidade do meio ambiente, conforme reza o art. $4^{\circ}$ da Lei ${ }^{\circ}$ 9.605/1998 (Lei de Crimes Ambientais); no contexto de antitruste, a personalidade jurídica do responsável por 
infração da ordem econômica poderá ser desconsiderada quando houver da parte deste abuso de direito, excesso de poder, infração da lei, fato ou ato ilícito ou violação dos estatutos ou contrato social, bem como, também será efetivada quando houver falência, estado de insolvência, encerramento ou inatividade da pessoa jurídica provocados por má administração, tal qual dispõe o art. 34 da Lei $n^{\circ}$ 12.529/2011 (Lei Antitruste); art. 18, $\S 3^{\circ}$, da Lei $n^{\circ}$ 9.847/99 (Lei do Abastecimento Nacional de Combustíveis); na seara trabalhista, em que além de vasto entendimento jurisprudencial, há regramento específico previsto no art. 855-A, da Consolidação das Leis do Trabalho (CLT), inovação trazida pela nominada reforma trabalhista; e, ainda, mesmo que observada certa controvérsia doutrinária, o art. 135, da Lei nº 5.172/1966 (Código Tributário Nacional-CTN), balizado pela súmula no 430, do Superior Tribunal de Justiça (STJ).

Observa-se assim, que o ponto comum entre essas esferas de aplicação da desconsideração da personalidade jurídica acima delineadas é que, em todas elas (civil, consumerista, de crimes ambientais, práticas antitruste ou seara trabalhista), há de se seguir, no plano procedimental, as regras insculpidas nos artigos 133 a 137, do novo Código de Processo Civil. E mais que isso: o incidente de desconsideração há de tramitar em juízo, pois, nesse contexto, somente pelo do exercício da jurisdição como função estatal, pode-se desprezar a personalidade de um sujeito com escopo de mitigar o princípio da autonomia patrimonial.

Em que pese consagrada em leis materiais, a desconsideração da personalidade jurídica carecia de uma processualização, de regulamentação por lei adjetiva para instrumentalizar aquilo já delineado por leis substantivas. Suprindo essa lacuna, o novo Código de Processo Civil trouxe previsão específica sobre o instituto acerca do procedimento a ser adotado para sua aplicação, conforme disposto nos artigos 133 a 137.

Assim, uma "advertência tem sido feita pela jurisprudência: tratando-se de regra de exceção, a interpretação e aplicação da desconsideração da personalidade jurídica devem ser feitas segundo interpretação restritiva. Em doutrina também prevalece esse entendimento" (THEODORO JÚNIOR, 2018, p. 419).

Ocorre que, em contraponto a este cenário em específico (observância ao que rezam os artigos 133 a 137, do CPC e, em especial, necessidade de procedimento judicial sob a forma de incidente para que haja pronunciamento do juízo acerca da desconsideração da personalidade), tem-se o quanto descrito na Lei $n^{\circ} 12.846 / 2013$, mais precisamente em seu art. 14. Explica-se.

\section{O ARTIGO 14 DA LEI N 12.846/2013 E SUA DEBILIDADE}

Imagine-se, hipoteticamente, que, em um caso concreto, a autoridade administrativa entenda ter havido abuso de personalidade de um sujeito empresário a enquadrar-se no art. $5^{\circ}$, da Lei Anticorrupção. Instaurado o Processo Administrativo de Responsabilização resolve a autoridade desconsiderar a personalidade jurídica. Haveria a autoridade de cientificar os sócios do sujeito empresário que teve sua personalidade desconsiderada, ou ainda, acerca da iminência disso acontecer ou bastaria notificar a sociedade, já que esta é um sujeito? Em sede administrativa, se o sócio, que é pessoa diversa do sujeito empresarial, não for chamado a integrar o processo administrativo, os efeitos da desconsideração sobre ele poderão recair? Não haveria ofensa às regras da Lei $n^{\circ}$ 9.784/1999? Pela dicção do art. 14, Lei no 12.846/2013, essas lacunas existem e, sem esforço inteligível, as respostas para elas seriam contrárias à eficácia daquele dispositivo.

Ainda tomando por base o exemplo exposto, suponha-se que em sede administrativa houve a desconsideração da personalidade jurídica, atingindo-se os sócios. Prontamente, a pessoa jurídica e seus sócios, cada um de per si, argumentam aquele ato administrativo pela via judicial. Contudo, como o Judiciário, não entrega a prestação jurisdicional em tempo razoável, persistindo por vasto tempo os efeitos da decisão administrativa. Este ato não mitigaria ou mesmo inviabilizaria o exercício da empresa (atividade) pelo sujeito empresário? Ou desmotivaria os sócios a continuar a querer praticar a livre iniciativa? E, se ao prestar a jurisdição, o Judiciário 
invalidasse a desconsideração praticada na via administrativa, as consequências danosas desta já não teriam se implementado no tempo, afetando, inclusive, a imagem e honra objetiva do sujeito empresário?

Essas indagações revelam um cenário de insegurança jurídica a afetar a própria ordem econômica, constitucionalmente prevista. A assertiva ganha relevo se for acrescentado ao debate o entendimento de que há um princípio da dignidade da pessoa jurídica a indicar necessária tutela de sua personalidade e honra objetiva (GONTIJO, 2008).

Assente que o nominado Processo Administrativo de Responsabilização previsto do art. $8^{\circ}$ até o art. 15, da Lei $\mathrm{n}^{\circ} 12.846 / 2013$, tem natureza jurídica de processo administrativo punitivo. Explica Moraes (2009, p. 58) que "por meio do processo administrativo punitivo pode a administração pública decidir por aplicar medida desfavorável ao administrado que com ela mantenha algum vínculo administrativo".

Em atenção ao problema de pesquisa, resta analisar os aspectos procedimentais trazidos pelo art. 14, da Lei ${ }^{\circ} 12.846 / 2013$, sobretudo, frente à nova dogmática adjetiva inaugurada pelo Código de Processo Civil (CPC) de 2015 e, mais ainda, tomados os princípios e preceitos constitucionais aplicáveis à matéria.

\subsection{Conflito de normas}

Em um primeiro olhar, considerados o notório anseio social comum pelo combate à corrupção e que se estaria resguardando o devido processo administrativo (em específico, contraditório e ampla defesa), aparentemente não haveria problema que, em sede de contencioso administrativo, se aplicasse a disregard of legal entity, tal qual sinala o art. 14, da Lei Anticorrupção. Inclusive se reconhece aqui que, no STJ, há um julgado, mesmo que isolado neste sentido, sobre o qual, à frente, de modo mais incisivo, será abordado. Todavia, prima facie, identifica-se um obstáculo àquela pretensão. Veja-se:

Até a edição da Lei $n^{\circ} 13.105 / 2015$, que instituiu o novo CPC, não havia regras instrumentais claras e consolidadas de como se proceder à desconsideração. Solucionando-se esse assunto, assenta a lei civil adjetiva:

Art. 133. O incidente de desconsideração da personalidade jurídica será instaurado a pedido da parte ou do Ministério Público, quando lhe couber intervir no processo.

$\S 1^{\circ}$ O $\mathrm{O}$ pedido de desconsideração da personalidade jurídica observará os pressupostos previstos em lei.

$\S 2^{\circ}$ Aplica-se o disposto neste Capítulo à hipótese de desconsideração inversa da personalidade jurídica.

Art. 134. O incidente de desconsideração é cabível em todas as fases do processo de conhecimento, no cumprimento de sentença e na execução fundada em título executivo extrajudicial.

$\S 1$ 을 instauração do incidente será imediatamente comunicada ao distribuidor para as anotações devidas.

$\S 2^{\circ}$ Dispensa-se a instauração do incidente se a desconsideração da personalidade jurídica for requerida na petição inicial, hipótese em que será citado o sócio ou a pessoa jurídica.

$\S 3^{\circ}$ A instauração do incidente suspenderá o processo, salvo na hipótese do $§ 2^{\circ}$. $\S 4^{\circ} \mathrm{O}$ requerimento deve demonstrar o preenchimento dos pressupostos legais específicos para desconsideração da personalidade jurídica.

Tomado o disposto nesse novel conjunto normativo, em especial o descrito no $\S 1^{\circ}$, do art.133, do CPC, tem-se que é pressuposto (para usar a expressão trazida pela lei) do instituto desconsideração que este se processe sob a batuta da jurisdição (o pedido é dirigido a um juízo), 
pois lugar adequado à sua verificação. Ocorre que, de outro lado, por meio do art. 14, da Lei $\mathrm{n}^{\circ}$ 12.846/2013 (pertencente à disciplina do Processo Administrativo de Responsabilização), poderse-ia desconsiderar a personalidade jurídica de um sujeito empresário no bojo de um processo administrativo, ou seja, sem intervenção da jurisdição.

Indene de dúvidas, instaurado um conflito, mesmo que aparente, de normas, pois há uma antinomia, ou seja, "situação que se verifica entre duas normas incompatíveis, pertencentes ao mesmo ordenamento e tendo o mesmo âmbito de validade" (BOBBIO, 1994, p. 88).

Percebe-se que o advento do regramento específico sobre o procedimento da desconsideração instaurado pelo novo CPC, que é de 2015, retirou a força normativa permissiva de, no caso da Lei $n^{\circ} 12.846 / 2013$, aplicar-se a teoria da penetração pela via de processo administrativo, necessitando-se, pois, em todo caso, de pronunciamento judicial. Sem rodeios, é o que se dessume da aplicação direta do $\S 1^{\circ}$, do art. $2^{\circ}$, do Decreto-lei $n^{\circ}$ 4.657/1942 (Lei de Introdução às normas do Direito Brasileiro (LINDB).

Não há que se falar em hipótese de incidência do $\S 2^{\circ}$, do art. $2^{\circ}$, da LINDB, pois os artigos 133 a 137 do CPC revogaram tacitamente o art. 14, da Lei Anticorrupção, haja vista que além da incompatibilidade entre a lei nova (2015) e a lei velha (2013), aquela passa a regular inteiramente a matéria - aspectos procedimentais da desconsideração da personalidade jurídica versada na lei anterior. Assim, todas as disposições desta, a esse respeito, deixam de existir, vindo a lei revogadora (CPC) substituir a antiga.

Nessa linha, o $\S 1^{\circ}$, do art. 133 do CPC se refere a regras instrumentais, tanto que sua redação diverge daquilo apregoado pelo $\S 4^{\circ}$, do art. 134, do CPC que, ao falar em pressupostos legais específicos, indica a adequação do caso concreto às hipóteses de incidência de direito material. Nesse particular, evidencia-se que inclusive o art. 50, do Código Civil remete à reserva de jurisdição, pois afirma que pode o juiz decidir acerca da desconsideração da personalidade jurídica.

Em reforço argumentativo, vislumbra-se a intenção do legislador ordinário de padronizar as regras instrumentais sobre a teoria da penetração, tanto que assentou no art. 1.062, do CPC, que o incidente de desconsideração da personalidade jurídica aplica-se ao processo de competência dos juizados especiais, local onde os processos são marcados, dentre outros, pela simplicidade e informalidade. Se até os procedimentos dos Juizados Especiais, mesmo com suas mitigadoras características, reclamam a reserva de jurisdição para desconsideração da personalidade jurídica, mais ainda há de submeter aquele primado constitucional para o fim aqui analisado, o processo administrativo. Inclusive, pois no Brasil adota-se o modelo inglês, a implicar a sistemática de jurisdição una.

\subsection{O ainda incipiente entendimento do STJ}

Não se olvida que o STJ possui julgado - mesmo que bem específico para não indicar algo consolidado na Corte Cidadã -, acerca da possibilidade de desconsideração da personalidade jurídica por meio de processo administrativo:

ADMINISTRATIVO. RECURSO ORDINÁRIO EM MANDADO DE SEGURANÇA. LICITAÇÃO. SANÇÃO DE INIDONEIDADE PARA LICITAR. EXTENSÃO DE EFEITOS À SOCIEDADE COM O MESMO OBJETO SOCIAL, MESMOS SÓCIOS E MESMO ENDEREÇO. FRAUDE À LEI E ABUSO DE FORMA. DESCONSIDERAÇÃO DA PERSONALIDADE JURÍDICA NA ESFERA ADMINISTRATIVA. POSSIBILIDADE. PRINCÍPIO DA MORALIDADE ADMINISTRATIVA E DA INDISPONIBILIDADE DOS INTERESSES PÚBLICOS.

- A constituição de nova sociedade, com o mesmo objeto social, com os mesmos sócios e com o mesmo endereço, em substituição a outra declarada inidônea para 
licitar com a Administração Pública Estadual, com o objetivo de burlar à aplicação da sanção administrativa, constitui abuso de forma e fraude à Lei de Licitações Lei n. ${ }^{\circ} 8.666 / 93$, de modo a possibilitar a aplicação da teoria da desconsideração da personalidade jurídica para estenderem-se os efeitos da sanção administrativa à nova sociedade constituída.

- A Administração Pública pode, em observância ao princípio da moralidade administrativa e da indisponibilidade dos interesses públicos tutelados, desconsiderar a personalidade jurídica de sociedade constituída com abuso de forma e fraude à lei, desde que facultado ao administrado o contraditório e a ampla defesa em processo administrativo regular.

- Recurso a que se nega provimento (BRASIL, 2003, p. 262).

Extrai-se, contudo, que neste julgado, que data de 2003 (dado este considerável), adotouse como fundamentos para se promover a desconsideração da personalidade jurídica ter sido a sociedade constituída com abuso de forma e fraude à lei (pressuposto da desconsideração), o fato de a Administração Pública ter de resguardar o princípio da moralidade administrativa e da indisponibilidade dos interesses públicos tutelados (justificativa autorizadora para que a Administração o pudesse fazer) e que, no caso concreto, fosse facultado ao administrado o contraditório e a ampla defesa em processo administrativo regular.

Ocorre que, indene de dúvidas, pode e deve a Administração Pública resguardar o princípio da moralidade administrativa e da indisponibilidade dos interesses públicos tutelados por meio de outras formas (e os instrumentos delineados na Lei $\mathrm{n}^{\circ}$ 8.429/1992 são prova disso), que não a invasiva ruptura, administrativamente, da autonomia patrimonial. Bem ainda, não somente se assegurar o contraditório e ampla defesa legitima a Administração Pública para que, no campo administrativo, desconsidere a personalidade jurídica de um sujeito, pois, a matéria é revestida de revelo constitucional.

Dessa feita, aquele entendimento do STJ, com a devida vênia, não reproduz a univocidade que a discussão reclama, a qual carece da palavra final do Pretório Excelso.

\subsection{Ilegalidade e lesão a preceitos constitucionais}

A postura desta República em relação à corrupção, na essência, perpassa pela adoção de politicas públicas que vão desde à educação e conscientização para a mudança de cultura do povo, pois medida profilática, até a efetiva operacionalização de mecanismos de combate dessa mazela.

Não raro, a corrupção enquanto problema de ordem social, política e econômica, promove um descolamento da ordem do plano político para a ordem do mundo jurídico, conforme identificam Madeira e Geliski (2019, p. 6). Há, no dizer de Barroso (2014, p. 34), um "certo avanço da justiça constitucional sobre o campo da política majoritária”. Com efeito, é fato notório que tribunais, sobretudo, constitucionais, têm se tornado protagonistas de discussões que, em regra, ocupavam espaço apenas na arena de atribuições a cargo do Executivo e do Legislativo.

Nesse contexto, descortina-se a relevância da jurisdição constitucional, que, segundo Agra (2015, p. 106):

é a função estatal que tem a missão de concretizar os mandamentos contidos na Constituição, fazendo com que as estruturas normativas abstratas possam normatizar a realidade fática. Esta exprime a intenção de estabilizar as relações sociais, de acordo com os parâmetros da Carta Magna, evitando o risco do arrefecimento de sua força normativa.

A partir do ponto controvertido estabelecido neste estudo, emerge a necessidade de se exercer, no contexto da jurisdição constitucional, as duas facetas da aplicação indireta da 
Constituição, quais sejam, a interpretação conforme a Lei Maior e o controle de constitucionalidade (BARROSO, 2014, p. 241). Com efeito, o juiz-intérprete há de utilizar a Constituição como parâmetro para aferir a validade daquela norma infraconstitucional (art. 14, da Lei no 12.846/2013), e não sendo o caso de declará-la inválida, atribuir a ela o melhor sentido possível segundo o norte constitucional.

Ratifica-se que a (im)possibilidade de desconsideração da personalidade jurídica pela via administrativa reclama atuação direta do Supremo Tribunal Federal em exercício de jurisdição constitucional, tal qual assentado pelo ministro Celso de Mello, no MS 32494 MC/DF [sic]:

[...] seja porque esta Suprema Corte ainda não se pronunciou sobre a validade da aplicação da "disregard doctrine" no âmbito dos procedimentos administrativos, seja porque há eminentes doutrinadores, apoiados na cláusula constitucional da reserva de jurisdição, que entendem imprescindível a existência de ato jurisdicional para legitimar a desconsideração da personalidade jurídica (o que tornaria inadmissível a utilização dessa técnica por órgãos e Tribunais administrativos), seja porque se mostra relevante examinar o tema da desconsideração expansiva da personalidade civil em face do princípio da intranscendência das sanções administrativas e das medidas restritivas de direitos, seja, ainda, porque assume significativa importância o debate em torno da possibilidade de utilização da "disregard doctrine", pela própria Administração Pública, agindo "pro domo sua", examinada essa específica questão na perspectiva do princípio da legalidade (BRASIL, 2013).

Frisa-se, contudo, que este caso concreto, a indicar leading case, está concluso ao relator desde 05.09.2018 e, justamente por estar o tema pendente de apreciação pelo STF, há necessidade de se esmiuçar a questão.

Afirma Didier Júnior (2012, p. 1- 4) que:

A exploração da atividade econômica, pela via empresarial, é manifestação do direito de propriedade [...]. A personalidade jurídica das sociedades é instrumento fundamental para a chamada iniciativa privada, realizando importantíssimo papel na propulsão da atividade econômica [...]. A pessoa jurídica é, portanto, um instrumento técnico-jurídico desenvolvido para facilitar a organização da atividade econômica.

Desse modo, não se poder olvidar que a personalidade, inclusive a jurídica, tem assento constitucional nos termos do art. $5^{\circ}$, XXIX, pois signo identificador e distintivo de um sujeito em relação ao outro. Como tal, afirma Diniz (2011, p. 28) que "dada essa previsão constitucional os direitos de personalidade vêm ocupando posição privilegiada, pois, fundamentais que são, carregam consigo o caráter de serem extrapatrimoniais, intransmissíveis, irrenunciáveis e imprescritíveis”. Nesse mesmo diapasão, reza o art. 52, do Código Civil que se aplica às pessoas jurídicas, no que couber, a proteção dos direitos da personalidade.

Ocorre que, retomando-se o objeto de fundo - desconsiderar-se a personalidade jurídica de um sujeito empresário no bojo de um processo administrativo, sem intervenção da jurisdição -, a conjuntura trazida pelo art. 14, da Lei Anticorrupção vai de encontro à dispositivos constitucionais, notadamente, direito constitucional à personalidade, separação dos poderes, reserva de jurisdição, juiz natural, devido processo legal e segurança jurídica. Em linhas gerais, a resposta constitucional e convencionalmente mais adequada, otimizadora do direito interno e consentânea com a interpretação mais garantidora dos direitos fundamentais recai sobre uma questão de princípio (SARMENTO; TAROCO, 2013, p. 91). Portanto, a interpretação daquele dispositivo legal há de ser feita sob o viés constitucional. 
Vê-se na Lei Anticorrupção que a instauração e o julgamento de processo administrativo para apuração da responsabilidade de pessoa jurídica cabem à autoridade máxima de cada órgão ou entidade do Poder Executivo (art. $8^{\circ}$, caput). Na prática, a instauração, instrução e julgamento do Processo Administrativo de Responsabilização, em âmbito federal, fica a cargo da CGU.

Assim, considerada a Lei $\mathrm{n}^{\circ} 12.846 / 2013$ se observa que, em um único sujeito (CGU, por exemplo), ter-se-iam concentradas as funções inquisitoriais, de parte, de detentor das provas, de custus legis, de julgador e credor do objeto das sanções naquele procedimento impostas. Cogita-se que essa situação vai de encontro às bases do Estado de Direito, pois, se estabelecer possibilidade de mitigação de direito constitucional fundamental à personalidade de um sujeito empresário a interferir na sua autonomia patrimonial e desembocando na esfera de responsabilidade de um sócio, tudo isso, sem a chancela do Judiciário, mais se amolda a um império sob comando déspota, em nítido detrimento dos primados, também constitucionais, da impessoalidade e do devido processo legal.

Na forma delineada pelo art. 14, da Lei Anticorrupção, a Administração Pública, em desobediência à separação dos poderes, imiscui-se em função reservadamente destinada ao Judiciário - aqui entendida como a imposição do tratamento de certas matérias apenas por meio de decisão judicial -, para, precariamente, praticar ato excepcionalíssimo, passível, inclusive, de pronta invalidação pelo judiciário, ante ao sistema de jurisdição una aqui adotado. Veja-se:

A essência do postulado da divisão funcional do poder, além de derivar da necessidade de conter os excessos dos órgãos que compõem o aparelho de Estado, representa o princípio conservador das liberdades do cidadão e constitui o meio mais adequado para tornar efetivos e reais os direitos e garantias proclamados pela Constituição. [...] O postulado da reserva constitucional de jurisdição importa em submeter, à esfera única de decisão dos magistrados, a prática de determinados atos cuja realização, por efeito de explícita determinação constante do próprio texto da Carta Política, somente pode emanar do juiz, e não de terceiros, inclusive daqueles a quem se haja eventualmente atribuído o exercício de 'poderes de investigação próprios das autoridades judiciais'. A cláusula constitucional da reserva de jurisdição [...] traduz a noção de que, nesses temas específicos, assiste ao Poder Judiciário, não apenas o direito de proferir a última palavra, mas, sobretudo, a prerrogativa de dizer, desde logo, a primeira palavra, excluindo-se, desse modo, por força e autoridade do que dispõe a própria Constituição, a possibilidade do exercício de iguais atribuições, por parte de quaisquer outros órgãos ou autoridades do Estado (BRASIL, 1999).

É certo que, em sede de processo administrativo, não se há de falar em estrita observância ao princípio do juiz natural e seu principal consectário, que é a imparcialidade, justamente, pois a autoridade administrativa está a buscar a supremacia do interesse público, mormente, secundário. Também não se tem a impossibilidade de a Administração Pública agir de ofício.

Por isso mesmo, o sujeito competente, para aplicar a teoria da penetração, haveria de ser aquele investido de jurisdição, como juiz natural, pois, nela não se permite espaço para parcialidades e pessoalidades no tratamento da personalidade de um acusado. Tanto é verdade que dispõe o art. 133, do CPC que o incidente de desconsideração da personalidade jurídica será instaurado a pedido da parte ou do Ministério Público, quando lhe couber intervir no processo. Logo, pela lógica do princípio da inércia, vedado instaurá-lo de ofício.

Ademais, se de um lado se clama democraticamente pelo combate à corrupção, de outro lado se clama em mesmo ou maior tom por se assegurar direitos constitucionais fundamentais. Assim, "a jurisdição constitucional pode ser compatível com a democracia, e será tanto mais legítima quanto mais contribuir para o seu aprimoramento” (MORO, 2004, p. 254). 
Analisando os aspectos processuais da desconsideração da personalidade jurídica, Didier Júnior (2012, p. 01) é categórico ao aduzir que "a desconsideração é uma sanção e, como tal, somente poderia ser aplicada se respeitado o devido processo legal". E este está sedimentado, a toda evidência, unicamente, nos artigos 133 a 137, do CPC.

Inclina-se a compreender, portanto, que o processo administrativo, que pode ser objeto de controle judicial, não se mostra lugar adequado para que se instaure, instrua e julgue a desconsideração da personalidade de um sujeito, sob pena de se ter um "poder punitivo informal" (ROCHA, 1997, p. 14).

Dado esse aspecto de sanção da desconsideração, inviável se cogitar que, na via administrativa, haja transmissão da pena de uma pessoa jurídica a outra (sócios), conforme o princípio da intranscendência subjetiva das sanções, consagrado pelo STF.

\section{CONCLUSÃO}

Objetivou-se, neste trabalho, tratar da conformação substancial do instituto da desconsideração da personalidade jurídica, analisar os aspectos procedimentais trazidos pelo art. 14, da Lei Anticorrupção, principalmente, frente à nova dogmática adjetiva inaugurada pelo Código de Processo Civil-CPC de 2015, observados os regramentos da Lei da Liberdade Econômica e, mais ainda, considerados os princípios e preceitos constitucionais aplicáveis à matéria.

A Lei $n^{\circ} 13.874 / 2019$, ao modificar o Código Civil, preceitua que a pessoa jurídica não se confunde com os seus sócios, associados, instituidores ou administradores, e que ela, pessoa jurídica, goza de uma autonomia patrimonial em relação àqueles. Essa autonomia patrimonial, nos moldes positivados pelo art. 49-A, do CC, é um instrumento lícito de alocação e segregação de riscos, estabelecido pela lei com a finalidade de estimular empreendimentos, para a geração de empregos, tributo, renda e inovação em benefício de todos.

Contudo, de fato, a prática revela que sujeitos empresários, dotados de personalidade jurídica, no exercício de atividades econômicas privadas e, inclusive, conexas à Administração Pública, incorrem em abuso da personalidade jurídica, caracterizado pelo desvio de finalidade ou pela confusão patrimonial. Essa conduta enseja desconsiderá-la para que os efeitos de certas e determinadas relações de obrigações sejam estendidos aos bens particulares de administradores ou de sócios da pessoa jurídica beneficiados direta ou indiretamente pelo abuso (art. 50, CC).

Da aplicação direta do $\S 1^{\circ}$, do art. $2^{\circ}$, do Decreto-lei no 4.657/1942 (Lei de Introdução às normas do Direito Brasileiro), conclui-se que o CPC, lei posterior, ao trazer regramento específico sobre as balizas procedimentais da desconsideração da personalidade jurídica, revogou a possibilidade de se fazê-lo por meio do procedimento administrativo de responsabilização, previsto na Lei $\mathrm{n}^{\circ} 12.846 / 2013$.

A análise do conteúdo normativo do art. 14, da lei Anticorrupção sob as balizas da jurisdição constitucional revelou que devido processo legal que se espera, neste caso, é o que se origina, desenrola e conclui sob a batuta da reserva de jurisdição, única função estatal apta a atuar no deslinde da temática. Com efeito, essa sistemática é a única apta a conferir à aplicação da disregard of legal entity segurança jurídica, pois um sujeito empresário investigado sob a égide da Lei Anticorrupção, que tenha sofrido ali injusta desconsideração e penalização, por óbvio, socorrerse-ia ao Judiciário e, mesmo se ali obtivesse sucesso na demanda, revertendo o ato administrativo, a mácula à atividade empresarial por ele desenvolvida, já haveria se consolidado, em detrimento, possivelmente, da função da empresa.

Com efeito, ao atuar em processo que verse sobre desconsideração da personalidade jurídica de um sujeito empresário, instaurando-o e conduzindo-o, a Administração Pública estaria, assim, a violar o primado da separação dos poderes, pois imiscui-se em atribuição destinada 
constitucionalmente apenas ao Judiciário (reserva de jurisdição) e, ainda sob o crivo do juiz natural, como mecanismo a impedir direcionamentos e parcialidades.

Do somatório dos fatores aqui listados e retomando o problema de pesquisa, descortinada está a inconstitucionalidade do art. 14, da Lei Anticorrupção, compreendendo-se, portanto, que o processo administrativo permanece nos limites de sua esfera, não sendo admitida a desconsideração da personalidade jurídica.

Nesse diapasão, aquele isolado julgado do STJ não encerra a discussão (ponto controvertido), pois, indene de dúvidas, pode e deve a Administração Pública resguardar o princípio da moralidade administrativa e da indisponibilidade dos interesses públicos tutelados por meio de outras formas (e os instrumentos delineados na Lei $n^{\circ} 8.429 / 1992$ são prova disso), que não a invasiva ruptura, administrativamente, da autonomia patrimonial.

A divergência de interpretação reclama, pois, atuação do STF para se conformar possibilidade da desconsideração da personalidade jurídica de um sujeito empresário por meio de um processo administrativo, considerados não os aspectos materiais do instituto que são de assente infraconstitucional, mas sim, o caráter instrumental a indicar colidência de direitos fundamentais. Isso ao que parece, não tardará a ocorrer, pois, no mínimo, avizinha-se o julgamento do MS 32494 MC/DF, pelo Pretório Excelso.

\section{REFERÊNCIAS}

AGRA, Walber de Moura. A Expansão Da Jurisdição Constitucional. Revista FIDES, v. 6, n. 1, p. 105-118, 2015.

BARROSO, Luís Roberto. O novo direito constitucional brasileiro: contribuições para a construção teórica e prática da jurisdição constitucional no Brasil. $3^{\mathrm{a}}$ reimp. Belo Horizonte: Fórum, 2014.

BRASIL. Constituição (1988). Constituição da República Federativa do Brasil. Brasília, DF, 05 outubro 1988. Disponível em:

<http://www.planalto.gov.br/ccivil_03/Constituicao/ConstituicaoCompilado.htm> Acesso em: 27 nov 2018.

Decreto-Lei no 4.657, de 4 de maio de 1942. Lei de Introdução às normas do Direito Brasileiro. Diário Oficial da União, Brasília, DF, 9 set. 1942. Disponível em: <http://www.planalto.gov.br/ccivil_03/Decreto-Lei/Del4657compilado.htm> Acesso em: 08 out 2018.

Decreto-Lei no 5.452 , de $1^{\circ}$ de maio de 1943. Aprova a Consolidação das Leis do Trabalho. Diário Oficial da União, Brasília, DF, 9 ago. 1943. Disponível em: <http://www.planalto.gov.br/ccivil_03/decreto-lei/Del5452.htm> Acesso em: 08 out 2018.

. Lei $\mathrm{n}^{\circ}$ 5.172, de 25 de outubro de 1966. Dispõe sobre o Sistema Tributário Nacional e institui normas gerais de direito tributário aplicáveis à União, Estados e Municípios. Diário Oficial da União, Brasília, DF, 27 out. 1966. Disponível em: <http://www.planalto.gov.br/ccivil_03/LEIS/L5172.htm> Acesso em: 27 nov 2018.

. Lei $\mathrm{n}^{\circ}$ 5.764, de 16 de dezembro de 1971. Define a Política Nacional de

Cooperativismo, institui o regime jurídico das sociedades cooperativas, e dá outras providências. Diário Oficial da União, Brasília, DF, 16 dez. 1971. Disponível em: <http://www.planalto.gov.br/ccivil_03/LEIS/L5764.htm> Acesso em: 27 nov 2018. 
Lei $n^{\circ} 8.078$, de 11 de setembro de 1990. Dispõe sobre a proteção do consumidor e dá outras providências. Diário Oficial da União, Brasília, DF, 12 set. 1990. Disponível em: <http://www.planalto.gov.br/ccivil_03/Leis/L8078compilado.htm> Acesso em: 27 nov 2018.

Lei $\mathrm{n}^{\circ}$ 8.429, de 03 de junho de 1992. Dispõe sobre as sanções aplicáveis aos agentes públicos nos casos de enriquecimento ilícito no exercício de mandato, cargo, emprego ou função na administração pública direta, indireta ou fundacional e dá outras providências. Diário Oficial da União, Brasília, DF, 03 jun. 1992. Disponível em: <http://www.planalto.gov.br/ccivil_03/LEIS/L8429.htm> Acesso em: 27 nov 2018.

Lei no 8.934, de 18 de novembro de 1994. Dispõe sobre o Registro Público de Empresas Mercantis e Atividades Afins e dá outras providências. Diário Oficial da União, Brasília, DF, 18 nov. 1994. Disponível em: <http://www.planalto.gov.br/ccivil_03/leis/L8934.htm> Acesso em: 27 nov 2018.

Lei $\mathrm{n}^{\circ}$ 9.605, de 12 de fevereiro de 1998. Dispõe sobre as sanções penais e administrativas derivadas de condutas e atividades lesivas ao meio ambiente, e dá outras providências. Diário Oficial da União, Brasília, DF, 13 fev. 1998. Disponível em: <http://www.planalto.gov.br/ccivil_03/LEIS/L9605.htm> Acesso em: 27 nov 2018.

Lei $\mathrm{n}^{\circ}$ 9.784, de 29 de janeiro de 1999. Regula o processo administrativo no âmbito da Administração Pública Federal. Diário Oficial da União, Brasília, DF, 1 fev. 1999. Disponível em: <http://www.planalto.gov.br/ccivil_03/LEIS/L9784.htm> Acesso em: 27 nov 2018.

Lei $\mathrm{n}^{\mathrm{o}} 10.406$, de 10 de janeiro de 2002. Institui o Código Civil. Diário Oficial da União, Brasília, DF, 10 jan. 2002. Disponível em: <http://www.planalto.gov.br/ccivIl_03/Leis/2002/L10406.htm> Acesso em: 27 nov 2018.

Lei $\mathrm{n}^{\circ}$ 12.529, de 30 de novembro de 2011. Estrutura o Sistema Brasileiro de Defesa da Concorrência; dispõe sobre a prevenção e repressão às infrações contra a ordem econômica; altera a Lei $\mathrm{n}^{\mathrm{0}}$ 8.137, de 27 de dezembro de 1990, o Decreto-Lei $\mathrm{n}^{\mathbf{0}}$ 3.689, de 3 de outubro de 1941 - Código de Processo Penal, e a Lei no 7.347, de 24 de julho de 1985; revoga dispositivos da Lei no 8.884, de 11 de junho de 1994, e a Lei no 9.781, de 19 de janeiro de 1999; e dá outras providências. Diário Oficial da União, Brasília, DF, $1^{\circ}$ nov. 2011. Disponível em: <http://www.planalto.gov.br/ccivil_03/_Ato2011-2014/2011/Lei/L12529.htm> Acesso em: 27 nov 2018.

Lei $\mathrm{n}^{\mathrm{o}} 12.846$, de $1^{\mathrm{o}}$ de agosto de 2013 . Dispõe sobre a responsabilização administrativa e civil de pessoas jurídicas pela prática de atos contra a administração pública, nacional ou estrangeira, e dá outras providências. Diário Oficial da União, Brasília, DF, 2 ago. 2013. Disponível em: <http://www.planalto.gov.br/ccivil_03/_ato2011-2014/2013/lei/112846.htm> Acesso em: 27 nov 2018.

Lei n ${ }^{\circ} 13.105$, de 16 de março de 2015. Código de Processo Civil. Diário Oficial da União, Brasília, DF, 17 mar. 2015. Disponível em: <http://www.planalto.gov.br/ccivil_03/_ato2015-2018/2015/lei/113105.htm> Acesso em: 27 nov 2018. 
. Lei $n^{\circ} 13.874$, de 20 de setembro de 2019. Institui a Declaração de Direitos de Liberdade Econômica; estabelece garantias de livre mercado; altera as Leis nos 10.406, de 10 de janeiro de 2002 (Código Civil), 6.404, de 15 de dezembro de 1976, 11.598, de 3 de dezembro de 2007, 12.682, de 9 de julho de 2012, 6.015, de 31 de dezembro de 1973, 10.522, de 19 de julho de 2002, 8.934, de 18 de novembro 1994, o Decreto-Lei $n^{\circ} 9.760$, de 5 de setembro de 1946 e a Consolidação das Leis do Trabalho, aprovada pelo Decreto-Lei ${ }^{\circ} 5.452$, de $1^{\circ}$ de maio de 1943; revoga a Lei Delegada $\mathrm{n}^{\circ}$ 4, de 26 de setembro de 1962, a Lei $\mathrm{n}^{\circ} 11.887$, de 24 de dezembro de 2008, e dispositivos do Decreto-Lei n ${ }^{\circ} 73$, de 21 de novembro de 1966; e dá outras providências. Diário Oficial da União, Brasília, DF, 20 set. 2019. Disponível em: < http://www.planalto.gov.br/ccivil_03/_Ato2019-2022/2019/Lei/L13874.htm\#art7> Acesso em: 17 abr. 2020.

. Superior Tribunal de Justiça. Súmula 430, Primeira Seção, julgado em 24/03/2010, REPDJe 20/05/2010, DJe 13/05/2010. Disponível em: <http://www.stj.jus.br/SCON/sumulas/toc.jsp?livre=430\&b=SUMU\&thesaurus=JURIDICO\&p=t rue\#DOC1> Acesso em: $06 \mathrm{dez} 2018$.

. Superior Tribunal de Justiça. RMS 15.166/BA, Rel. Ministro Castro Meira, Segunda Turma, julgado em 07/08/2003, DJ 08/09/2003, p. 262. Disponível em: < https://ww2.stj.jus.br/processo/revista/inteiroteor/?num_registro=200200942657\&dt_publicacao= 08/09/2003> Acesso em: 06 dez 2018.

Supremo Tribunal Federal. Mandado de Segurança no 23452, Relator(a): Min. Celso de Mello, Tribunal Pleno, julgado em 16/09/1999, DJ 12-05-2000 PP-00020. Disponível em: <http://portal.stf.jus.br/processos/detalhe.asp?incidente=1763585> Acesso em: 06 dez 2018.

Supremo Tribunal Federal. Mandado de Segurança no 32494-MC/DF, Relator(a): Min. Celso de Mello, 11.11.2013. Disponível em: <http://portal.stf.jus.br/processos/detalhe.asp?incidente=4484385> Acesso em: 06 dez 2018.

BOBBIO, Norbeto. Teoria do ordenamento jurídico. Trad. Cláudio de Acco e Maria Celeste C. J. Santos. 4. ed. Brasília: Edunb, 1994.

CAMPOS, Patrícia Toledo de. Comentários à Lei no . 12.846/2013-Lei Anticorrupção. Revista Digital de Direito Administrativo, v. 2, n. 1, p. 160-185, 2015.

CGU-CONTROLADORIA-GERAL DA UNIÃO. Lei Anticorrupção. Disponível em: <http://www.cgu.gov.br/assuntos/responsabilizacao-de-empresas/lei-anticorrupcao>. Acesso em: 18 out 2018.

COELHO, Fábio Ulhoa. Manual de Direito Comercial. 23. ed. São Paulo: Saraiva, 2011.

DIDIER JÚNIOR, Fredie. Aspectos processuais da desconsideração da personalidade jurídica. 2012. Disponível em: <http://www.frediedidier.com.br/wpcontent/uploads/2012/02/aspectos-processuais-da-desconsideracao-da-personalidadejuridica.pdf> Acesso em 10 nov 2018.

DINIZ, Maria Helena. Manual de Direito Civil. São Paulo: Saraiva, 2011. 
Importância da função social da empresa. Revista Jurídica, Unicuritiba, v. 02, n. 51, Curitiba, 2018. pp. 387-412.

GONTIJO, Vinícius José Marques. Do princípio da dignidade da pessoa jurídica. Revista de Direito Mercantil, São Paulo, v. 149/150, p. 151-158, jan./dez. 2008.

MADEIRA, Lígia Mori; GELISKI, Leonardo. O combate a crimes de corrupção pela Justiça Federal da Região Sul do Brasil. Revista de Administração Pública, 2019.

MORAES, Flavia Albertin de. A teoria da desconsideração da personalidade jurídica e o processo administrativo punitivo. Revista de Direito Administrativo, v. 252, p. 45-65, 2009.

MORO, Sergio Fernando. Jurisdição constitucional como democracia. São Paulo: Revista dos Tribunais, 2004.

NEGRÃO, Ricardo. Manual de Direito Empresarial. 8. ed. São Paulo: Saraiva, 2018.

RIBEIRO, Marcia Carla Pereira; DINIZ, Patrícia Dittrich Ferreira. Compliance e Lei Anticorrupção nas empresas. Revista de informação legislativa, v. 52, n. 205, p. 87-105, 2015.

ROCHA, Carmem Lucia Antunes. Princípios constitucionais do processo administrativo brasileiro. Revista de direito administrativo, v. 209, p. 189-222, 1997.

RODRIGUES JÚNIOR, Otávio Luiz. A lei da liberdade econômica e as transformações no Código Civil brasileiro. In: GOERGEN, Jerônimo. Liberdade Econômica - o Brasil livre para crescer. 2019. p. 123-131. Disponível em: <https://aquanticacontabilidade.com.br/webfiles/uploads/arquivo/site/1beb05f3260626831375b1dae21477cb.pdf\#page=122>. Acesso em 17 abr. 2020.

ROSA, Márcio Fernando Elias. Corrupção como entrave ao desenvolvimento. Revista do Tribunal Regional Federal da $1^{\text {a }}$ Região, v. 16, n. 8, ago. 2004.

SARMENTO, Vitor Seidel; TAROCO, Lara Santos Zangelorame. Entre a Jurisdição Constitucional Interna e a Internacional: ADPF 153 e Caso" Julia Gomes Lund e Outros Vs. República Federativa do Brasil". Revista de Direito Brasileira, v. 4, n. 3, p. 70-98, 2013.

SILVA, Rodrigo Martins da. A desconsideração da personalidade jurídica no direito tributário: dogmática e análise da jurisprudência brasileira. 2015. 174f. Dissertação (Mestrado em Direito) - Pontifícia Universidade Católica de São Paulo-PCU/SP, 2015.

THEODORO JÚNIOR, Humberto. Curso de direito processual civil. 59. ed. rev., atual. e ampl. Rio de Janeiro: Forense, 2018.

VIDO, Elisabete. Curso de Direito Empresarial. 4. ed. rev., atual. e ampl. São Paulo: Revista dos Tribunais, 2015.

ZANETTI, Adriana Freisleben de. Lei Anticorrupção e Compliance. Revista Brasileira de Estudos da Função Pública - RBEFP, Belo Horizonte, ano 5, n. 15, p. 35-60, set./dez. 2016. 